\title{
ROLE OF INFORMATION AND PROMOTIONAL STRATEGIES FOR INDIAN PHARMACEUTICAL FIRMS IN THE AGE OF DIGITAL MARKETING
}

\author{
Dr. Kamath Madhusudhana \\ Director of Lalita Clinic, Medico legal advisor Kamath and Kamath Associates \\ Former Associate Professor, Division of Ayurveda, Centre for Integrative Medicine and Research \\ (CIMR), Manipal Academy of Higher Education, Manipal, Karnataka, India -576 104
}

Article DOI: https://doi.org/10.36713/epra6577

\begin{abstract}
"I think the biggest innovations of the 21st Century will be the intersection of ...biology and technology. A new era is beginning..."-Steve Jobs

According to WHO, Promotional materials for pharmaceutical products should be accurate, fair and objective and presented in such a way as to confirm not only fulfil legal requirements but also to high ethical standards. India has pharmaceutical marketing is reaches 55 billion US dollars by 2020.

The improper strategy of introducing of a product whether in form of the diet, nutraceutical, or medicinal products result in noteworthy, while occasionally dangerous, result in community ${ }^{1}$ The objective of this paper is to synthesis the existing information on current status; explore the potential opportunities and constraints the Role of Information and Promotional Strategies India. ${ }^{2}$
\end{abstract}

\section{BACKGROUND}

Now a day's almost all big pharma giants will focus on well-established markets in developing countries or countries under the poverty line for their patented products central agencies, producers, presentation, promotion agencies, The most common issues in case of pharma marketing facing are

1. Patent versus generic one.

2. Outcome of research and development.

3. Spiraling health care budget across the world.

Nowadays India is the fastest growing market in all the sectors including pharma one.MNC's are made strategic shift towards India, India in 10 to 15 years will become the capital for non-communicable diseases. New agendas like Govt. open market policy and open insurance sector as well as privatization Make in India policies plays a vital role in this arena. In the case of India now universal pharma giants realize that it is possible to produce significant outcome from India, were almost pharm products are either lifesaving drugs or anti-infective ones. Business attitude offers a break for startups operations to develop in rapid mode. The World Health Organization (WHO) addresses cardinal health as a global strategy in 2020-2024, and its digital health policy draft defines digital health as "the field of knowledge and practice associated with the development and use of digital technologies to improve health" 3

It is not only necessary to develop a new molecule but it is also then to promote the already existing drug molecules. Indian pharma market constituted with ten thousand plus companies. These MNC's are not only concentrating on dietary supplements and nutraceuticals. But they also focus on 


\section{SJIF Impact Factor 2021: 7.13| ISI I.F.Value:1.241| Journal DOI: 10.36713/epra2016 EPRA International Journal of Research and Development (IJRD)

generic molecules. It is observed that these firms are throwing away outdated Marketing ideology. This new technology ranges from scientific listing to doctors from using newer systems for better insights focus on issues like patient compliance. Before Lockdown due to COVID -19, shows that India will be one of the fastest developing countries in the Asia Pacific region. Adding to it India should grow at a confounding 31\% per annum in coming next five years. ${ }^{4}$

Now total Indian national position in the world is transformed. It gains the worlds third-largest manufacture zone steadily people giving more concentration towards their health, especially in preventive and maintenance aspect. But MNC's must know that the big pharmaceuticals grow here only when they adopt an India centric strategy which focuses on the operational management to take suitable decision to observe current and future trends periodically 5,6,7,8. After 2014 the formation of the stable central government and policies like 'Make in India' and 'Swach Bharat Abhiyaan' brings the Pharma market into to some extent right track.

Unfortunately, even after promising steady growth Indian pharmaceutical industry observes brisk pace for a sum of a large number of small-scale pharmaceutical setups were obliged to cut down as well as shut down their business from 2008. Whether it is a big or small business, the need for pharmacoeconomics and advance in business economics has been growing in the current years. The Business Intelligence allows Industry to squeeze statistics from different podiums and white colour people must take appropriate decisions yields tangible investments.

Pharmaceutical industries one more problem is life-saving medicines should be sold at a nominal price to the great segment of the population of the country, as per government norms. under the 'Essential Commodities Act'. The Business Intelligence systems analyses the forecast with latent decision of pharma marketing polices must trust because of the shift in pharma marketing. Various social media like Google, Facebook, Whatsapp and Others, which are the association for performing study projected to an understanding of Artificial intelligence skills for the wellbeing of society 9 The details of defendants, project team technology, evaluation of strategy, and ethics, which were captured in line with the WHO's building blocks for health systems $10,11,12,13$

\section{DISCUSSION}

According to an intelligence source, the progress rate in India is at $25 \%$ to $40 \%$ per annum. Pharma Business, Various pharmaceutical involved in a revolution and It need of to build a philosophy rather than focusing too much on various new technology, build a patient-centric environment which helps the people start trusting in our pharma business, It is observed that US models won't work in India, Here demographic factors also play a vital role. So Integrated operations bring consistency and cost efficiencies It is observed tactics have got more consideration in the last two decades both domestic and international market. The growth and success of business firms are directly associated with the marketing strategies ${ }^{14}$.

It is quite common rural area requires more medicines than urban due to the conditions like improper sanitization, cleanness, lack of improper drinking water leads to germ-infested conditions like various infections like Malaria, Kala-Azar, Cholera which needs the consumption of more medicine. Hence campaign using leaflets, newspaper, Ads on boards are not so influential one. As It is observed that the most of rural people are not well-educated so efficiently they would be communicated through a roadshow, proper usage of Celluloid Screen etc. 15 With promoting advanced Business intelligence and the progress in promotion approaches and skills at the universal level the last era, the pharma industry has also industrialized in a way similar to further profit-driven industries ${ }^{16}$. To facilitate customers the business enterprise should also be enumerated in various search engines and entertain e-commerce ${ }^{17}$. In simple online marketing has its issues and concerns, ${ }^{18}$ The strategies like Digital Marketing has meaningfully changed the healthcare and Pharma sector ${ }^{19}$ while digitalization boost Pharma industry ${ }^{20}$.

\section{CONCLUSION}

Hereby I , conclude that Information and Promotional Strategies for Indian Pharmaceutical Firms in the age of Digital Marketing, it is still infancy in the age. However, especially due to the COVID-19 pandemic, there were inadequate lessons in this particular domain and hence this could be the very right time more appropriate now due to the COVID-19 pandemic.

Some Pharmaceutical Industries are still using outdated programming strategies that have been replaced throughout the world, improper the usage of state-of-the-art analytical and decision .This is the right time to use supportive systems like Python, R, Geospatial Technology and Artificial Intelligence, Marketing Intelligence and Business Intelligence. The strategies used by pharmaceutical firms are must be proactive in nature. Pharmaceutical Marketing is a purpose of feeling the pressure to generate and implement business organized strategies in an 


\section{SJIF Impact Factor 2021: 7.13| ISI I.F.Value:1.241| Journal DOI: 10.36713/epra2016 ISSN: 2455-7838(Online) EPRA International Journal of Research and Development (IJRD)

organized form. "strategies and approaches used by the pharmaceutical industry can also focus on the research as their basic outline, through strategic Pharma Companies find out the sales power to win the support of their clients and at the same time hold their accountability by providing clinicians with the muchneeded material and distributing the best products to the community.

\section{REFERENCE}

1. Wilcock $M$ Pharmaceutical marketing-greater than the sum of its parts? Drug and Therapeutics Bulletin Published Online First: 21 August 2020. doi: 10.1136/dtb.2020.000004

2. Nautiyal S, Smitha KC, Kaechele H. Medicinal Plant Biodiversity in India: Harnessing Opportunities for Promoting Livelihood and Food Security. InSocio-economic and Eco-biological Dimensions in Resource use and Conservation 2020 (pp. 135-169.

3. Dhingra D, Dabas A. Global Strategy on Digital Health. Indian Pediatr 2020 Apr 25;57(4):356-358.

4. https://mopharma.com/blogs/pharma-digitalmarketing-12.html accessed on 2020-09-28

5. Sophie P, Javier GP, Andrew C, Zsuzsanna V. From treatment to prevention: The evolution of digital healthcare. https://media.nature.com/original/magazine accessed on 2020-09-23

6. Merchant RK, Inamdar R, Quade RC. Effectiveness of Population Health Management Using the Propeller Health Asthma Platform: A Randomized Clinical Trial. J Allergy Clin Immunol Pract 2016;4(3):455-463.

7. Merchant $R$, Szefler SJ, Bender BG, Tuffli $M$, Barrett MA, Gondalia R, et al. Impact of a digital health intervention on asthma resource utilization. World Allergy Organ J 2018;11(1):28

8. Shull JG. Digital Health and the State of Interoperable Electronic Health Records. JMIR Med Inform 2019 Dec 01;7(4).

9. https://www.partnershiponai.org/ accessed on 2020-01-25

10. Ahmed T, Lucas H, Khan AS, Islam R, Bhuiya A, Iqbal M. eHealth and mHealth initiatives in Bangladesh: a scoping study. BMC Health Serv Res 2014;14:260 https://gs.statcounter.com/os-marketshare/mobile/pakistan accessed on 2020-09-27

11. https://www.pta.gov.pk/en/telecom-indicators accessed on 2020-09-27

12. World HO. Everybody's business strengthening health systems to improve health outcomes: WHO's framework for action. Geneva: World Health Organization; 2007:978-992.

13. Pensap S, Mekhum W. Role of Demographic Factors and Stakeholders in Determining the Marketing Strategies of Pharmaceutical Companies in Thailand. Systematic Reviews in Pharmacy. 2020;11(4):45-51.

14. Agrawal B. Promotional Strategies for Indian Pharmaceutical Companies in the Era of Digital Marketing.

15. Khanna V, Ahuja $R$, Popli H. ROLE OF ARTIFICIAL INTELLIGENCE IN PHARMACEUTICAL MARKETING: A COMPREHENSIVE REVIEW. Journal of Advanced Scientific Research. 2020 Aug 1;11(3).

16. Mishra R, Sanghvi D. Promotional Strategies of Pharmaceutical Organizations through Online and Social Media.

17. Bharskar GR, Siddheshwar S. Digital Marketing In Pharmaceutical Sector.

18. Kamath $M$, Brijesh $K$, Mallya SV. Online marketing of herbal medicines issues and concerns: A SWOT analysis. Research Journal of Pharmacy and Technology. 2018;11(11):5058-60.

19. Ben-Jebara M, Modi SB. Product personalization and firm performance: An empirical analysis of the pharmaceutical industry. Journal of Operations Management. 2020 Jul 29.

20. Lindgren A, Mohidin D. Applying Digital Marketing Methods in the Healthcare Industry: A Case Study at Immuneed. 